\title{
Pneumologia
}

\section{Pulmonary artery thrombosis in home patient with a mild COVID-19 disease}

Alessandro Graziani ${ }^{1, *}$, Marco Domenicali ${ }^{2}$, Grazia Zanframundo ${ }^{1}$, Francesco Palmese ${ }^{1}$, Barbara Caroli ${ }^{1}$, Pierluigi Cataleta ${ }^{3}$, Ludovico Graziani ${ }^{4}$

${ }^{1}$ Medicina Interna, Ospedale Santa Maria delle Croci, Viale Randi 48121, Ravenna, Italy

${ }^{2}$ Medicina Interna, Università Degli Studi Bologna, Bologna, Italy

${ }^{3}$ Reumatologia Ospedale Santa Maria delle Croci, Ravenna, Italy

${ }^{4}$ Università Cattolica Del Sacro Cuore, Roma, Italy

Abstract

\section{English:}

COVID-19 has been described as the cause for a proinflammatory and hypercoagulable state that induces thrombotic vascular lesions and, in more severe cases, disseminated intravascular coagulation. Increased values of $D$-dimers are related to the severity of the disease and are associated with worst prognosis. Intensive care studies reported an increased risk of pulmonary embolism and venous thrombosis diseases in COVID-19 compared with the historical control group even in patients who underwent the low-molecular-weight heparin (LWMH) prophylaxis. Patients with COVID-19 who have a stable clinical condition do not require hospitalisation and are treated at home with symptomatic therapy. LWMH is reserved for those with reduced mobility. In this case report, we describe a COVID-19 patient with pulmonary artery thrombosis treated at home.

Keywords

COVID-19 $\cdot$ D-dimers $•$ pulmonary artery thrombosis $\bullet$ interstitial pneumonia

\section{Tromboza arterei pulmonare la pacient cu boala COVID 19 forma usoara aflat la domiciliu}

Rezumat

Romanian:

COVID-19 a fost descris ca fiind responsabil de status proinflamator și hipercoagulant capabil să inducă leziuni trombotice vasculare, și în cazuri mai severe, coagulare intravasculară diseminată. Valorile crescute ale D-dimerilor se corelează cu o boală mai severă și un prognostic mai prost. Studiile efectuate în secțiile de terapie intensivă au raportat un risc mai mare de embolie pulmonară și tromboză venoasă profundă la pacienții cu COVID -19 comparativ cu grupul de control, chiar și la acei pacienți la care s-a efectuat anticoagulare profilactică. Pacienții cu COVID-19, stabili din punct de vedere clinic nu nécesită spitalizare și sunt tratați acasă cu simptomatice. Heparinele cu greutate moleculară mică sunt rezervate pentru acei pacientiii care nu se mobilizează. Acest articol descrie cazul unui pacient cu infecție COVID-19 tratat la domiciliu care a dezvoltat, tromboză arterială

Cuvinte-cheie pulmonară.

COVID-19・D-dimeri, tromboză arterială pulmonară • pneumonie interstițială

*Corresponding author: Alessandro Graziani, Medicina Interna, Ospedale Santa Maria delle Croci, Viale Randi 48121, Ravenna, Italy.

E-mail: alessandro.graziani@auslromagna.it

ว Open Access. ๑ 2020 Graziani et al., published by Sciendo

(cc) BYKNC.ND This work is licensed under the Creative Commons Attribution-NonCommercial-NoDerivs 4.0 License. 


\section{Introduction}

Arising in China in the winter of 2019, the infection with the novel coronavirus - severe acute respiratory syndrome coronavirus 2 (SARS-CoV-2), was described in people who had been exposed to seafood market in Wuhan. Since then, there has been a quick spread of the disease, leading to a global pandemic of coronavirus disease (COVID-19) (1). After an incubation period of 4-5 days, patients who become symptomatic have fever, cough, sore throat, malaise and myalgias. A minority of cases occur with gastrointestinal symptoms (anorexia, nausea and diarrhoea) or neurological symptoms (anosmia and ageusia). Most patients (80\%) have mild or moderate disease (including those with mild pneumonia), $15 \%$ had severe disease (diffuse lung injury) and $5 \%$ had critical illness (2). Patients with respiratory failure are usually monitored in hospital, while those with mild illness usually recover at home with supportive care and isolation. Self-monitoring of oxygen saturation is a useful tool for people who are at high risk for complications (lung diseases, cardiovascular diseases, diabetes and obesity) (3). COVID-19 has been well described as the cause of a proinflammatory and hypercoagulable state. After 7-14 days from the onset of the symptoms, there is a systemic increase of inflammatory mediators and cytokines (CK) (4). The inflammatory response induces a procoagulant effect and a diffuse endothelial damage that determine thrombotic vascular lesions and disseminated intravascular coagulation (DIC) in patients with critical illness $(5,6)$. Increased values of $D$-dimers are related to the severity of the disease and are associated with the worst prognosis. Intensive care studies reported an increased risk of pulmonary embolism (PE) and venous thrombosis diseases (VTD) in COVID-19 compared with the historical control group even in patients who underwent the low-molecular-weight heparin (LMWH) prophylaxis (7). Monitoring D-dimers blood value has to be useful in identifying cases with a poor prognosis and higher risk of thrombotic phenomena (8). Stable patients infected with COVID-19 do not require hospitalisation and are treated at home (9). LMWH is reserved for those with reduced mobility. Home-treated patients do not undergo laboratory exams or radiological investigations in any phases of the disease. In this case report, we describe a COVID-19 patient with pulmonary artery thrombosis, treated at home with hydroxychloroquine.

\section{Case presentation}

A 57-year-old male with a history of virus B hepatitis (VHB) was admitted to our hospital after 3 days history of fever and chest pain. He was an active person and did not have any history of chronic medication. The diagnosis of COVID-19 was based on the detection of SARS-CoV-2 by means of reverse transcriptase polymerase chain-reaction (RT-PCR) assay on nasopharyngeal swab 1 month before admission. After the diagnosis, he started hydroxychloroquine $(400 \mathrm{mg} /$ day) for 10 days.

On examination, he was breathing regularly without dyspnoea with body temperature $37.7^{\circ} \mathrm{C}$, heart rate 88 beats/min, blood pressure $145 / 65 \mathrm{mmHg}$, respiratory rate 16 breaths/min, oxygen saturation $96 \%$ at room air and body mass index (BMI) $26 \mathrm{~kg} / \mathrm{m}^{2}$. Heart sounds were regular and lung auscultation was clear in both lungs. Laboratory test showed: white blood cell count $(\mathrm{WBC})=12.960 \mathrm{mmc}$, neutrophils $10.730 \mathrm{mmc}$, C-reactive protein (CRP) $53 \mathrm{mg} / \mathrm{L}$ (normal value $(\mathrm{NV})<5$ ), alanine aminotransferase $(\mathrm{ALT})$ $214 \mathrm{U} / \mathrm{L}$, D-dimers 3,742 mg/L (NV < 500), HIV-negative. Arterial blood gases (ABG) in breathing air showed a $\mathrm{pH}$ of $7.45, \mathrm{PaCO}_{2} 40 \mathrm{mmHg}, \mathrm{PaO}_{2} 89 \mathrm{mmHg}$, satO $=95 \%$. Electrocardiography (EKG) was unremarkable. Doppler ultrasonography (DU) of the lower limbs was negative

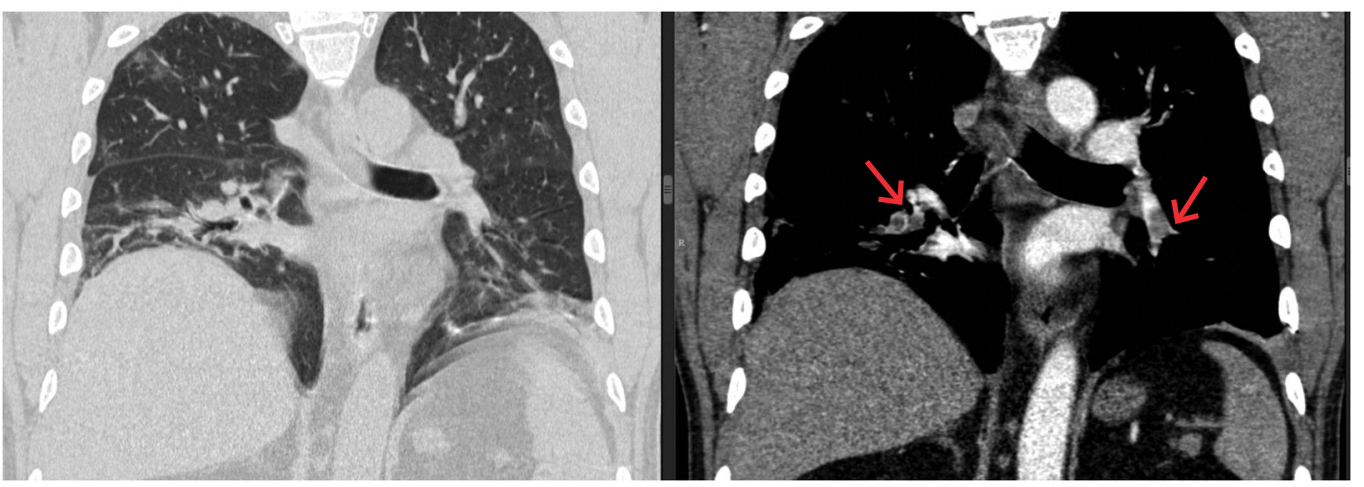

Figure 1. CT thorax with contrast (sagittal view) showing bilateral lower arterial thrombosis (red arrows). 
for deep venous thrombosis (DVT) while a computed tomography pulmonary angiography (CTPA) demonstrated a bilateral arterial thrombosis associated with ground glass opacity (GGO) in the lower lobes (Figure 1). His nasal swab resulted positive for COVID-19. The patient started anticoagulation with LWMH 8,000 $\mathrm{U}$ twice a day. Abdominal ultrasonography did not demonstrate any signs of cirrhosis, hepatic focal lesions or portal hypertension.

Echocardiogram showed normal left and right ventricular wall motion, left ventricle ejection fraction $60 \%$ and a normal pulmonary artery pressure $(20 \mathrm{mmHg})$.

After 5 days of hospitalisation, laboratory exams showed WBC 8,720 mmc, ALT $207 \mathrm{U} / \mathrm{L}$ and D-dimer 1,425 mg/L. The patient had stable clinical condition without dyspnoea and fever, and the chest pain gradually improved. During discharge (13 days later), he continued anticoagulation therapy with warfarin. His nasal-pharyngeal swab was negative for COVID-19.

\section{Discussion}

This article describes the case of a patient with mild COVID-19 and pulmonary artery thrombosis initially treated at home. Our patient never performed blood chemistry tests or radiological investigation during the home treatment period of COVID-19 infection. For this reason, it was not possible to determine when the thrombotic event occurred. CTPA showed a distal bilateral thrombosis of the lower pulmonary arterial branches where the pulmonary inflammation is most diffuse. It is noteworthy that Doppler ultrasound was negative for DVT. As current data suggest, coagulation disorders are significantly increased in COVID-19 patients, especially among those with severe disease. Indeed, it was observed that COVID-19 may predispose to both venous and arterial thrombosis due to inflammatory cascade, hypoxia and endothelial injury (10). Post-mortem evidence shows microvascular platelet-rich thrombotic depositions in small vessels of the lungs and other organs (11). The endothelial vascular damage inside the injured areas may predispose to the development of a primitive pulmonary artery thrombosis. A recent study reported the findings of 12 autopsies where the authors noted a high incidence of PE with or without underlying DVT $(12,13)$.

In conclusion, we described a patient with mild COVID-19 disease who developed a pulmonary vascular injury, strictly correlated with an elevation of D-dimer values, without any signs of respiratory failure. Based on these studies, elevation of D-dimer levels could identify patients at risk for concurrent thrombotic diseases. We suggest a periodical monitoring of coagulation parameters and prophylactic dose of $\mathrm{LMWH}$ even in home patients with mild COVID-19 disease. Further studies will be needed to address this issue.

\section{Ethical approval}

Inform consent was obtained from the patient in order to participate to write the article.

\section{Conflicts of interests}

The authors declare that they have no conflicts of interest.

\section{References}

1. Xu Z, Shi L, Wang Y, Zhang J, Huang L, Zhang C, et al. Pathological findings of COVID-19 associated with acute respiratory distress syndrome. The Lancet Respiratory Medicine. 2020;8(4): 420-422. Available from: doi.org/10.1016/ S2213-2600(20)30076-X.

2. Wu Z, McGoogan JM. Characteristics of and important lessons from the coronavirus disease 2019 (COVID-19) outbreak in china: summary of a report of 72314 cases from the Chinese Center for Disease Control and Prevention. JAMA. 2020 February 24 (Epub ahead of print). Available from: doi:10.1001/ jama.2020.2648

3. Huang C, Wang Y, Li X, Ren L, Zhao J, Hu Y, et al. Clinical features of patients infected with 2019 novel coronavirus in Wuhan, China. Lancet. 2020;395: 497-506.

4. Connors JM, Levy JH. Thromboinflammation and the hypercoagulability of COVID-19. Journal of Thrombosis and Haemostasis. 2020;18(7): 1559-15615. Available from: doi:10.1111/ jth.14849.

5. Klok, FA, Kruip MJ, van der Meer NJM, Arbous MS, Gommers DAMPJ, Kant KM, et al. Incidence of thrombotic complications in critically ill ICU patients with COVID-19. Thrombosis Research. 2020 Apr 10. Available from: doi:10.1016/j. thromres.2020.04.013

6. Lillicrap D. Disseminated intravascular coagulation in patients with 2019-nCoV pneumonia. Journal of Thrombosis and Haemostasis. 2020;18(4): 786-787. Available from: doi:10.1111/ jth.14781. Epub 2020 Mar 24

7. Tang N, Bai H, Chen X, Gong J, Li D, Sun Z. Anticoagulant treatment is associated with decreased mortality in severe coronavirus disease 2019 patients with coagulopathy. Journal of Thrombosis and Haemostasis. 2020;18: 1094-1099.

8. Zhang L, Xhinsheng Y, Fan Q, Liu H, Liu X, Liu Z, et al. D-dimer levels on admission to predict in Hospital mortality in patients 
with covid 19. Journal of Thrombosis and Haemostasis. 2020;18: 1324-1329.

9. Gandhi RT, Lynch JB, Rio CD. Mild or moderate Covid 19. The New England Journal of Medicine. 2020;34: 1-9. DOI: 10.1056/ NEJMcp2009249.

10. Terpos E, Ntanasis-Stathopoulos I, Elalamy I, Kastritis E, Sergentanis T, Politau M, et al. Hematological findings and complications of COVID-19. American Journal of Hematology. 2020;95: 834-847.

11. Fox SE, Atmakbekov A, Harbert JL, Li G, Brown JQ, Vander Heide RS. Pulmonary and cardiac pathology in Covid-19: The first autopsy series from New Orleans. MedRxiv 2020; [Epub ahead of print].

12. Wichmann D, Sperhake JP, Lütgehetmann $M$, Steurer $S$, Edler C, Heinemann A, et al. Autopsy findings and venous thromboembolism in patients with COVID-19: a prospective cohort study. Annals of Internal Medicine. 6 May 2020. [Epub ahead of print]. [PMID: 32374815] Available from: doi:10.7326/ M20-2003

13. Chen J, Wang $X$, Zhang $S$, et al. Findings of acute pulmonary embolism in COVID-19 patients. SSRN Electron J 2020; published online April 11. DOI:10.2139/ssrn.3548771. 